\title{
LITERATUUR EN LEWENSBESKOUING - MET BESONDERE VERWYSING NA DIE MODERNE AFRIKAANSE KUNSPROSA*
}

Een van die belangrikste sake wat vir ons opnuut geaktualiseer is deur tendensies in die hedendaagse Afrikaanse letterkunde èn veral deur die bekroning met die Hertzogprys van Sewe dae by die Silbersteins, is die verhouding tussen lewensbeskouing en kunsbeskouing in die algemeen, en meer in besonder dié tussen lewensbeskouing en letterkunde. Hierdie laasgenoemde aspek wil ek graag behandel, maar dan in sy konteks en slegs so volledig as wat die tydsbeperking my toelaat.

Ek sê met opset: „vir òns geaktualiseer”, want ons, u en ek, is ten nouste betrokke. Elke boek of publikasie veronderstel 'n driehoeksverhouding: skrywer-geskrif-leser. Die een wat die gouste uitgeskakel word, is die skrywer: sodra die boek verskyn, word die skrywer ook maar 'n leser. Dan geld vir hom ook: Wat ek geskryf het, het ek geskryf tensy hy begin reviseer en herskryf, soos André P. Brink met Lobola vir die lewe gemaak het, of Marthinus Nijhoff met sy verse.

Wat eintlik met publikasie gebeur, is dat die leser teenoor die geskrif te staan kom, en die blote feit dat die geskrif publiek gemaak is, gee elke leser die goeie reg om na lese 'n mening daarop na te hou, die inhoud van die geskrif te aanvaar of te verwerp, te prys of te laak, of albei. Of dié oordeel gèldig is, hang egter van die aard daarvan af.

Met ander woorde, ons, lesers, wat in 'n mindere of meerdere mate 'n lewensbeskouing daarop nahou, reageer in terme van daardie lewenshouding/lewensiening/lewensbeskouing op die boek waarmee ons gekonfronteer word. Elke leser is in ' $n$ mindere of meerdere mate kritikus wat ontleed, beskryf, interpreteer, vergelyk, waardeer/takseer. By die meeste geskied hierdie proses onvakkundig en onvolmaak, by ander meer wetenskaplik en meer geslaagd. Maar niemand

\footnotetext{
* Inougurele rede gehou by die aanvaarding van 'n professoraat in Afrikaans-Nederlands aan die P.U. vir C.H.O., op 14 Mei 1965, deur prof. dr. P. D. van der Walt.
} 
mag vir selfs die oningeligste leser sê: Jy mag nie 'n oordeel oor hierdie boek uitspreek nie. Hoogstens mag jy 'n dwase of verkeerde oordeel weerlê en 'n beter een in die plek daarvan gee - as jy kan.

Dit is dus die eerste saak wat ek wil tuisbring: ons is almal, miskien onwillens en onwetens, betrokke by ons literatuur. Nie net omdat ons lesers of Afrikaners is nie, maar veral op grond van ons lewensbeskouing of gebrek daaraan. In ons geval, as belydende Christene, as Gereformeerdes in die omvattende sin van die woord, die kring nog nouer getrek: as Calviniste, ons wat verbonde is aan hierdie Universiteit wat die wetenskap - ook die literatuurwetenskap - beoefen in die lig van Gods Woord: ons is ten nouste en onontkombaar betrokke by gebeure en tendensies in ons letterkunde. Ons is rekenskap en standpunt nie net teenoor onsself verskuldig nie, maar ook teenoor die buitewêreld - enersdenkendes èn andersdenkendes.

Daarom het ek dit goed gedink om vanaand hierdie onderwerp van lewensbeskouing en literatuur te bespreek minstens die probleem te stel, al kan ek dan nie die laaste woord in die oplossing spreek nie. Dis dus nie bloot 'n literêr-akademiese saak nie; dis ook 'n publieke aangeleentheid, en waar die meeste van die aanwesiges hier nie literêre vaklui is nie maar lesers - dus deel van die algemene leespubliek - het dié onderwerp vir my belangwekkend genoeg gelyk vir 'n geleentheid soos hierdie.

Maar dit ís ook 'n akademiese aangeleentheid, want waar ons die letterkunde aan die universiteit by uitnemendheid op 'n wetenskaplike grondslag bestudeer, èn op gespesialiseerde wyse, sal ons onder meer - en hier aan die P.U. vir C.H.O. dalk boweal - te doen kry met die probleem van lewensbeskoulike of ideologiese elemente of waardes in ons literatuurbenadering en beoordeling.

En my plek vanaand hier agter die kateder illustreer meteen nie alleen my plek en funksie in die literatuurondersoek nie, maar ook dié van elke letterkunde-onderwyser of literatuurkundige: ons staan in die klas tussen die boek en die nie so rype student, in die rubriek of tydskrif of vakwetenskaplike publikasie tussen die boek en die publiek/lesers. Daar hoef (behoort!) natuurlik nie so 'n middelman te wees nie, maar in die praktyk is hy veelal daar: as spreker, as dosent, as kritikus. 
En dit is ' $n$ verantwoordelikheid waarvan ons ons maar al te deeglik bewus is.

Nie alleen is vir ons almal die verhouding literatuurlewensbeskouing van aktuele belang nie; dis opnuut van belang. Hiermee uil ek - en daarom het ek die woord "opnuut" in my aanvangsin gebruik - te kenne gee dat dit nie nou uitsluitend die Sestigers is wat opeens en vir die eerste keer hierdie saak onder ons, lesers, se aandag gebring het nie. Alles was nie maar pais en vree tussen leser (verstaan ook: kritikus) en geskrif (verstaan miskien ook skrywer, want die skrywer moes dikwels as apologeet agterna optree, soos Leroux of Brink tans) van die begin van ons letterkunde af nie. Wel het die redes vir die misverstand of botsing tussen geskrif en publiek gewissel, maar daar was byna altyd 'n lewensbeskoulike element in betrokke.

Wanneer Klaas Waarzegger (Louis Henri Meurant) die eerste Afrikaanse boek omstreeks 1860 publiseer, gaan die openbare debat nie net oor die kwessie van die voor- en nadele van die afskeiding van die Oostelike Provinsie nie, maar die skrywer word ook daarvan beskuldig dat hy Hotnots-Hollands as skryfmedium gebruik. Dus: nie net politieke beginsels is op die spel nie, maar ook artistieke: sy taal is volgens baie 'n kunswaardige literêre medium. Klaas Waarzegger se antwoord was: Hy gebruik nie Hotnots-Hollands nie, maar wel Dopper-Hollands, en dít is ' $n$ beskaafde en waardige voertuig vir wat hy te sê het. Die geskiedenis het Klaas Waarzegger gelyk gegee.

Baie jare later, teen die einde van die $19 \mathrm{e}$ eeu, publiseer ds. S. J. du Toit die eerste historiese roman in Afrikaans: Die koningin van Skeba. Min verhale in ons taal het soveel inslag gevind by die lesers as juis hierdie een van Salomo se ou goudvelde in Sambesia en die legendariese koningin van Skeba en haar verhouding tot die groot koning van Israel.

Maar min verhale het ook die destydse lesers so ontnugter as hierdie een. Nou moet ons in gedagte hou dat die lesers van die tydskrif Ons Klyntji waarin dié roman aanvanklik stuksgewys verskyn het, meestal die plattelandse Afrikaners was: landelike mense, die boerebevolking, oor die algemeen literêr ongeskoold. Die meeste van hulle het hierdie historiese roman as feitelik wáár beskou, want die skrywer doen in der daad baie moeite om ' $n$ illusie van waarheid in 
sy verhaal te skep, veral deur middel van aanknopingspunte met bekende Bybelse en historiese feitlikhede.

$\mathrm{Na}$ aanleiding van navrae deur sy lesers moes ds. Du Toit daarop wys dat die roman fiksie is en nie feit nie, verbeeldingswerk en nie waarheid van die alledaagse werklikheidsorde nie. Vir sy ongeskoolde lesers wat nie mooi tussen verdigsel enersyds en waarheid andersyds, d.w.s. tussen literêre of fiktiewe waarheid en die gewone werklikheid of historiese waarheid kon onderskei nie, was die skrywer se bekentenis skokkend - veral vir hulle wat hom geken het, wat gesê het: Fanie sal nie lieg in 'n boek nie; vir dié wat beweer en geglo het: 'n predikant sal nie leuens kwytraak nie.

Wat die leserspubliek dus hier van die literatuur vervreem het, was 'n onvermoë om te onderskei tussen leuen en fiksie, tussen romanwerklikheid en die realiteit van uur en feit. Hulle het die skeppende verbeeldingsarbeid van die kunstenaar misken. Vir diesulkes was dit dus fundamenteel 'n religieus-morele kwessie van: Jy mag nie lieg nie. Dus 'n saak van lewensbeskouing.

Hierdie probleem van die eeuwending is intussen opgelos, hoewel miskien nog nie vir alle lesers ten volle nie, want dit lyk my daar is slegs vandag nog mense wat bv. 'n gedig as 'n biografiese dokument lees of ' $n$ roman as 'n blote lewensnit beskou. Maar hieroor later. Hoe dit ook sy, soos daar nuwe en andersoortige letterkunde verskyn het, het daar vars en ander besware teen die literatuur gekom. Die misverstande tussen lesers en geskrifte het blykbaar altyd bestaan, en indien daar nie juis misverstande was nie, dan wel tog meningsverskille en selfs ergernis.

Toe Ampie in 1924 verskyn, was daar ook maar ontevredenheid: Van Bruggen sou dan 'n al te roue werklikheid in sy roman geskep het, daar was woorde e.d.m. wat nie al te kies was volgens die smaak van baie nie. (Ou Goor Dawid (bl. 55): „Jy moet vrek! Verdomde kind!...” Ampie (bl. 81): „So wragtig, sy moet nou kom! ..."). Vandag is Ampie 'n klassiek in ons prosakuns, nog meer as die pre-literêre geskrifte van Meurant en Du Toit. Daarom kyk 'n jonger geslag verbaas op as Van Wyk Louw in 'n koerantbrief wys op die besware wat destyds teen Ampie gegeld het. Dié besware het gou vervlugtig en Van Bruggen het skool gemaak: in sy kielsog ontstaan ' $n$ druk navolging van die uitbeelding van armblankes. Maar na die baie Ampies en Annekies word daar mettertyd 
gepleit om knap kêrels en mooi nooiens in ons prosakuns, kaviaar en sjampanje.

Die vraag duik onmiddellik op: het die literatuur dan steeds gelyk? Is dit die lesers wat tekort skiet om die nuwe te verstaan en na waarde te skat? Wil die leser hom in die verhaalkuns slegs herken in die geïdealiseerde mens en nie in 'n eerlike of selfs eensydige beeld van die kunstenaarsiening nie? Is dit vir ons 'n vingerwysing om 'n wag voor ons mond te plaas en ons slegs met die grootste versigtigheid oor eietydse literatuur uit te laat? Ek noem dié dinge in die verbygaan, want dit is immers deel van die probleem waarop ons ons hier besin. Laat ons dus 'n moontlike antwoord net so 'n rukkie laat oorstaan.

Sedert Ampie het ons verhalende prosa stil-stil sy gang gegaan; jy kan maar sê: byna verstil. Daarom kan Van Wyk Louw in sy boekie Vernuwing in die prosa praat van die ban van die gemoedelike lokale realisme waarin ons prosa soveel jare lank gevange gesit het. (Hy het nagelaat om die skynwaarheid van die vertroetelende romantiek daarby te noem.) Werke wat die gemoedere van die leserspubliek in beroering bring, was daar nie juis nie: nie ten opsigte van die hoë artistieke peil daarvan nie en nie t.o.v. die lewenswaardes wat sterk opvallend in die werke gehuldig word nie. Die klompie goeie prosawerke tussen Ampie en die sestiger jare het enersyds hulle regmatige erkenning gekry, soos dié van Van Bruggen, Malherbe en C. M. van den Heever; en andersyds het die erkenning wel laat maar tog oorvloedig gekom, soos vir M.E.R. en J. van Melle.

Maar die morele problematiek wat struktuurmomente in werke soos Laat vrugte en $\mathrm{Bart} \mathrm{Nel}$ is, het skaars, indien enige, aandag ontvang. Miskien omdat Oom Sybrand se hardvogtigheid en die kerkraadslede se starre domheid ons aller simpatie met die jongmense wek en alles tog eindelik regkom, of omdat Bart Nel die nasionale Afrikaner se standpunt ten aansien van die Rebellie verteenwoordig. Maar nou dat daar teen ons nasionale Afrikanerregering dade van opstand en geweld plaasvind, kyk jy met nuwe oë na die rebel van 1914 , Bart Nel. En jy vra jou af: Is die morele geregverdigdheid van Bart Nel se opstand teen die wettig verkose regering in die roman voldoende gekonstitueer, soos wel die geval is met Bart se weiering om sy vrou wat egbreuk gepleeg het terug te vat? 
Ek wil maar net wys dat lewensbeskoulike probleme van die kant van die leser altyd daar was vir wie dit wou raaksien, soos ook in die werke van Willem van der Berg, bv. Reisigers na nêrens.

Maar sedert die verskyning van W. E. G. Louw se versebundel Die ryke dwaas (1934) het die ongekende en boeiende opbloei van ons digkuns ons aandag so in beslag geneem dat ons nie veel tyd en energie aan die verhalende prosa en die drama geskenk het nie. En miskien tereg ook, want gehalte laat hom oral en altyd geld.

Nou is die opvallende juis dit: as 'n mens die poësie van Dertig, Veertig, Vyftig op die keper beskou, dan vind jy daarin idees, lewensbeskouings, onderwerpe, temas, "tonele", beelde, woordgebruik waarteen 'n mens sou verwag dat die Afrikaanse leespubliek heftig te velde sou trek. Ek noem hier maar net die verskillende evolusionistiese Godsbegrippe by dié digters. 'n Bietjie onnoukeurig sou ek dit só wil stel: daar is min van die gewraakte elemente in die werk van Brink en Leroux waarvoor jy nie analogieë sal kry in dié van Van Wyk Louw en Opperman nie. En dié digters se werk is tog ook al bekroon, ook met die Hertzogprys. Maar ' $n$ openbare herrie, 'n soort beeldestorm, was daar nog nooit teen die poësie nie.

Miskien is die antwoord baie eenvoudig: Die deursneeleser ken nie juis die digkuns van Van Wyk Louw, Opperman of Blum nie. Hier en daar het wel 'n stem opgegaan teen 'n bepaalde onderdeel, soos Opperman se knallende kwaggas, of 'n gedig soos sy Kersliedjie wat sommige vir heiligskennis aangesien het, maar die hele "wêreld" van daardie digkuns het nog nooit so onder skoot (spervuur!) gekom soos die stuk verbeelde werklikheid wat in bv. Lobola vir die lewe, Die ambassadeur, Sewe dae by die Silbersteins of Een vir Azazel geskep word nie.

Persoonlik glo ek dat slegs 'n geringe element van oorsaak vir die verskil in benadering van die poësie teenoor die prosa in onbekendheid gesoek moet word. Die wesenlike oorsaak lê in 'n saak wat ek hoërop aangeroer het: lesers staan Vir hulle is poësie... nou ja, poësie: verbeeldingswerk, onvergoelikender teenoor digkuns as teenoor prosaverhale. konkreet, louter fiksie, en dus eintlik ontoerekenbaar indien iets skokkends daarin sou voorkom. Die publiek (en kritici!) 
gun die digkuns sy tradisionele andersheid, sy rebelsheid.

Maar verhalende prosa! Dié is vir die lesers 'n weergawe van die werklikheid, konkreter, 'n afspieëling van die wêreld waarin hulle hul bevind - eintlik 'n deel van daardie alledaagse werklikheid, of altans ' $n$ skriftelike verlengstuk daarvan. Daarom is sake wat deel vorm van die verhaal vir hulle sonder meer wáár, die plesierige sowel as die onaangename vir hulle van persoonlike belang; vgl. Die Du Plooys van Soetmelksvlei.

Die maatskappy het hom in ons tradisionele prosa meestal aanvaarbaar, dikwels vermooi, afgespieël gesien, maar nou bring die prosa van Sestig 'n abrupte breuk, 'n ander werklikheidsbeeld èn kunsgestalte daarvan, soos ek weldra sal aantoon. En dit na die vertroude realistiese of romantiserende regionalisme (streekskuns). Daar het dus 'n vervreemding tussen leser en literatuur ontstaan, 'n vervreemding wat dikwels in die hand gewerk word deur 'n hiper-individualistiese verhaalstruktuur, veruysingstegniek en selfs styl en onortodokse tipografie.

In 'n groot mate dus dieselfde vraagstuk waarmee ds. Du Toit destyds gesit het: sy lesers se onvermoë om die fiktiewe karakter van sy tweelaagverhaal te begryp, èn sy hiperfonetiese spelling te waardeer.

Is die probleem van die botsing tussen die werklikheidsbeeld van die leser en dié wat in die fiktiewe verhaal of die omgeskepte, geherorganiseerde werklikheid van die roman gehuldig word nou hiermee opgelos? Sekerlik nie. Dit is nie maar dat die skrywers (en literatore!) ironies-spottend kan sê dat die nuwe maar altyd onwelkom is by die goegemeente, en dat min mense ooit tevrede is met 'n onopgesmukte foto van hulself, en daarmee die hele saak as dwaasheid aan die kant van die beswaarde lesers kan afmaak nie.

Daar het, soos nou byna oorbekend, in die laat vyftiger en begin sestiger jare 'n nuwe impuls in ons prosa gekom. 'n Vars geslag prosateurs het aan die woord gekom, en die hoop op vernuwing in ons prosa was nie meer (soos W. E. G. Louw dit eenmaal gestel het) op die ongeborenes gevestig nie. Die herout van die vernuwing was sekerlik Jan Rabie met sy Een-en-twintig, maar daar was ook Etienne Leroux met Die eerste lewe van Colet, Hilaria en Die mugu. Verder moet genoem word Dolf van Niekerk en Chris Barnard. Maar die aller- 
duidelikste manifestasie van die verandering in die Afrikaanse prosa was André P. Brink se Lobola vir die lewe wat opgevolg is met Die ambassadeur en nou met Orgie. En toe word Leroux se Sewe dae by die Silbersteins bekroon, en die vervolg daarop verskyn: Een vir Azazel.

Van Wyk Louw het in sy genoemde werkie oor die prosa voorspel dat indien daar 'n vernuwing sou kom, dit sal wees t.o.v. stof of struktuur of styl of lewensbeskouing, of dan al vier elemente in onderlinge verband, met die lewenshouding as die aktiverende kern. So het dit dan ook in der daad gebeur, en die Afrikaanse leser staan dikwels versteld voor die vreemde wêreld wat in hierdie verhaalkuns geskep word, die vreemde lewensbeskouing wat meestal daarin gehuldig word, veral die eksistensialisme, en/of die vreemde nyse waarop die vormgewing geskied. (Hoe vreemd of nuut alles vir 'n wyer verband is, dus teen die agtergrond van die wêreldliteratuur, laat ek daar.)

Nou is dit seker waar dat die gemiddelde leser weens sy dalk vanselfsprekende beperkings dikwels nie te vertrou is in sy uitsprake oor, sy selfs verwerping van die ,malkuns van Sestig" nie. By wyse van spreke: tussen die hele ou lot herken hy net vir generaal De Wet!

Maar wát nou van die literatuurkundige, of die redelik geskoolde in die letterkunde?

Laat ek dus presiseer:

1) die soort letterkundige wat ek in gedagte het;

2) die bepaalde boeke, dus die soorte literatuur wat 'n probleem skep;

3) wat die verhalende prosaliteratuur as verskynsel in die besonder is;

4) die lewensbeskoulike element in die verhalende prosa, dus die substraat van denke wat daarin ingebed is;

5) die werkwyse van die literator;

6) die moontlike botsing van lewensbeskouings of werklikheidsbeelde;

7) 'n voorlopige oplossing.

I. In verband met die eerste punt (die soort letterkundige) kan ek sê: Daar gaan nooit enige probleem wees vir die onverskillige nie, of vir die dilletant wat nie indringend met die literatuur omgaan nie; of vir die man wat hom as 
'n suiwer esteet beskou èn die letterkunde as 'n blote spel met woorde; of vir hom wat 'n prinsipieel vreemde lewensbeskouing èn alles wat dit tot gevolg het in die woordkunswerk wel op sekere voorwaardes kan aanvaar, bv. as dit oortuigend uitgewerk is of indien die kunswerk nietemin 'n lewenswaarheid uitbeeld.

Maar ek bedoel nie dié soort literator nie - wel die Christenletterkundige; meer in besonder: die Calvinistiese literator - hy vir wie die Bybel, synde die Woord en geopenbaarde Wil van God, in álle sake die hoogste gesag is, hy wat hom voor hierdie gesag buig en hom daaraan onderwerp. Nou weet ek baie goed dat die Bybel net so min 'n handboek vir die estetiek of die literatuurwetenskap is as wat dit vir die wetenskap in die algemeen is. Die Bybel spreek hom nie direk uit oor die woordkuns nie. Wel bevat dit woordkuns van 'n bepaalde soort, bv. die Psalms, of die boek Job of die Hooglied. En dan het ek wel al op 'n karakteristiek van 'n bepaalde stuk woordkuns in die Bybel afgekom - vgl. Prediker 12 : 10 waar daar staan: „Die Prediker het gesoek om welgevallige woorde te vind en wat reg geskrywe is - woorde van waarheid".

Maar normatief in 'n streng letterkundige sin is die Bybel nie. Nietemin skep en handhaaf die Heilige Skrif godsdienstig-sedelike norme wat geldig is vir die mens se hele lewe: dus ook vir sy literatuur en sy omgang met die literatuur. Selfs in die lááste instansie behoort die letterkunde tot eer van God te wees.

Verder kan ek nou net namens myself praat in hierdie opsig en bv. sê: as daar 'n stuk letterkunde is waarin bv. egbreuk as verskynsel of boustof aanvaar word of goedgepraat word sonder enige korrektief of kritiek - hoe subtiel dit ook al mag wees - dan moet ek standpunt inneem teenoor dié stuk literatuur. Daarom het ek ook al seker 'n jaar gelede toe ek Adam Small se digbundel $S \hat{e}$ sjibbolet in die „Tydskrif vir Geesteswetenskappe" geresenseer het, sekere dinge daarin as Godslasterlik verwerp en dit pertinent gestel dat daar vir my hoër waardes en norme is as wat vandag aanvaar word as die suiwer estetiese.

II. Maar dit bring my dadelik by die tweede punt: die soort letterkunde. $\mathrm{Ek}$ het in gedagte, om steeds konkreet en ter sake te bly, 'n bepaalde soort boek wat vir my en vele 
ander 'n probleem of probleme skep: boeke soos Lobola vir die lewe, Die ambassadeur, Sewe dae by die Silbersteins, Een vir Azazel, Windroos, Orgie, om enkeles te noem. Hierdie werke kan as verteenwoordigend van die jongste Afrikaanse prosaliteratuur beskou word, ook kwalitatief. Sewe dae by die Silbersteins is suiwer literêr-struktureel gesien sy bekroning waardig, en Windroos kan beskou word as 'n soort manifes van die kunsrigting van die Sestigers. Dit bevat benewens die voorwoord talle gemeenskaplike en tiperende kenmerke.

In verband hiermee, vergun my die volgende opmerking: Prosa het altyd 'n demokratiese karakter gehad - vgl. die nederige taaluitinge in prosa van die Middeleeue, of die volksboeke van die 16e eeu, of die roman sedert die 18e eeu. Nou eers met die Sestigers word die prosa hier by ons (elders het dit eerder gebeur) verhef tot 'n soort aristokrasie en meer bepaald gerig tot ' $n$ geselekteerde leserskring. Daar is dus die verwagte reaksie van die verbysterde algemene leespubliek. Die eienaardige teenstrydigheid val op: toe die prosa gerig was op die volksmens, was dit verhaalfigure epies, heroïes, aristokraties en daar was 'n herkenbare agtergrond en sterk storie. Nou dat die prosa gerig is op die aristokrasie van die gees of intellek, is die verhaalfigure nederig, naamloos (soms byna gesigloos), ontredderd, willoos, pateties (Cees Nooteboom: „De ridder is gestorven"); die milieu bisar of neerdrukkend alledaags; die intrige bestaan skaars, terwyl 'n swaar vrag denke in die roman ingeskeep word. Ons sien in dié prosa 'n moderne elkerlyk in 'n kosmiese situasie. 'n Opvallende hedendaagse struktuurtegniek om die verhaal universele geldigheid te gee, om die betekenisdigtheid te versterk, is die gebruik van 'n oerteks, bv. ' $n$ mite as basis of as stramien waarop die skrywer sy patroon weet - vgl. Azazel of Dwaal of Orgie. Die veranderde werklikheidsbeeld van die moderne skrywer laat hom nie net met die struktuur van die verhaal eksperimenteer om 'n toereikende uitdrukkingsvorm te vind nie, maar dit manifesteer hom ook in die styl en die slotkeuse. Onderwerpe soos die seksuele word met wat dié skrywers noem „eerlikheid" ontgin; en kyk maar na die styl van Rabie se Een-en-twintig of Brink se Orgie of Lobola. Die styl in lg. werk sal vir vele abrakadabra wees; en die wêreld op realiteit wat in bv. Die ambassadeur of Sewe dae geskep word en die waardes wat in dié verhaalwêreld gehuldig word, vir baie ontstellend. Ook die visuele anbod van die boek is 
meer as dikwels so onortodoks, onkonvensioneel dat die leser dit vreemd vind en gemakshalwe sommer wil afwys as 'n reklameset, bv. Orgie wat dwars gedraai moet word, tweestemmig in kolomme verloop, talle toegewinge doen aan die liries-poëtiese, verskeie lettertipes gebruik, kris-kras druk, Kalahari's wit papier en vreemde Kongo's git-pik-swart bladsye!

Ek het hoërop gesê boeke soos hierdie skep 'n probleem. Watter soort probleem? Dié sal ek aanstons probeer aantoon, maar ek wil eers die derde punt aanraak, nl.

III. Wat prosaliteratuur as verskynsel in die besonder is.

Dit behoort vir almal duidelik te wees dat ek dit het oor literatuur en nie pornografie of vuilskrywery nie. En dan ook literatuur van aanvaarde goeie gehalte. Hier handel ek nou meer in besonder oor prosaverhaalkuns. Prosa staan teenoor vers, is in 'n sekere sin 'n minder gebonde vorm as vers, maar het tog ook weer sy eie wetmatighede waarop ek skaars hier in alle besonderhede kan ingaan sonder om die hooftema van my diskoers skade te berokken. Die prosaverhaal moet ons ook sien nie sommer as 'n lukraak vertelling nie, maar as 'n kunstig gestruktureerde geheel waarvan die elemente of samestellende dele 'n ,organisme" vorm, 'n sinvolle eenheid. Dié wet van samehang geld vir alle literatuur, maar in die verhaalkuns is die saamhangende elemente: die storie of intrige (gebeure), die persone en agtergrond betrokke by hierdie gebeure, die atmosfeer, die styl (dus bepaaldelik woordgebruik). M.a.w. 'n organiese stel verhoudings wat 'n eenheid vorm, 'n eenheid wat hom duidelik openbaar in die tema wat op epiese wyse (vertellend) losgemaak word uit die stof.

As verskynsel is die geslaagde verhaal 'n eie wêreldjie wat met woorde geskep word, net soos die gedig of drama, maar dis tog ook ánders. (Ook hierop kan ek nie breedvoeriger ingaan sonder om te veel af te dwaal nie.) Daarby moet ons ook onthou dat blote beskrywing of reportage van die werklikheid nog geen verhaalkuns is nie. Die herskeppende vermoë van die kunstenaar is hier die kwalifiserende faktor: hy selekteer uit die werklikheid èn die verbeelding, hy herrangskik en bou om 'n sinvolle, afgeronde geheel, dus skone patroon te maak. Daar is dus 'n sekere willekeurigheid en 'n verbeeldingselement. Maar die willekeurigheid moet verband hou met die (moontlike) gelowigheid en ervaring of kennis 
van die leser, verband hou met die moontlik kenbare werklikheid, want daar is in die woordkuns ook so iets soos die wetmatigheid van ooreenstemming.

Nietemin, wat ek wil beklemtoon, is dat bv. 'n romanverhaal wesenlik 'n verbeeldingsproduk is, dat daardie fiktiewe verhaalwêreld slegs tussen die buiteblaaie van die boek be staan. Dit lê as 't ware daar nie-bestaande tot tyd en wyl iemand dit lees en op sy sekondêre wyse herskep. Die prosaverhaal is ook op 'n besondere manier aan die tyd gebonde, ook vir sy interpretasie, sy opstanding in die gees van die leser. Dus anders as die beeldhouwerk of skildery of kort gedig wat eintlik met een oogopslag oorsien kan word, of die drama wat sigbaar vir die toeskouer voorgestel word. Op ' $n$ besondere wyse is die leser skeppend aktief by die prosaverhaal betrokke, by hierdie stuk fiksie.

Twee probleme steek dadelik kop uit:

1) Is die leser se interpretasie of herskepping van die werk korrek?

2) Is dit moontlik om die woorde en dade van fiktiewe verhaalkarakters te gaan beoordeel asof hulle lewende, verantwoordelike mense is? Is homo fictus en homo sapiens identiek? M.a.w. as 'n karakter in ' $n$ storie laster, laster hy in der daad, en wie is verantwoordelik vir sy sonde: die skrywer, die drukker, of ek as leser wat die drukwerk artikuleer?

IV. Dit bring ons by punt vier: die lewensbeskoulike element in die prosaliteratuur. Ons aanvaar dat die verhaal geen klakkelose reproduksie van die werklikheid gee nie, of 'n spieëlbeeld daarvan soos so baie teoretici sedert die Grieke geglo het. Maar die verband tussen die literatuur, of die verhaal in die besonder, en die konkrete uerklikheid van tyd en stof is nie te misken nie. Daarom praat kenners van die letterkunde ook van die hoërop genoemde wetmatigheid van ooreenstemming (,truth of correspondence") naas die wetmatigheid van samehang (,truth of coherence"). In die verbygaan wys ek op die uitwerking van twee fiksiewerke: Uncle Tom's Cabin en die Amerikaanse Burgeroorlog, Das Leiden des jungen Werthers en die selfmoorde.

Die verhaalskrywer werk met realiteitsbestanddele: bv. met taal, met mense soos daar bestaan of mag bestaan, dito voorvalle, ens. Ook met lewensbeskouing en waardes; en veral in die moderne roman is daar so 'n sterk denklaag. In die 
verhaal kan ingebed wees die skrywer se lewensb!skouing sonder dat die karakters dié lewensbeskouing uitspreek, maar die somtotaal van al die verhaalelemente, die tema, is 'n uitdrukking van dié lewenshouding. Of die karakters handel en praat volgens ' $n$ bepaalde lewensbeskouing wat hulle huldig, bv. aan die slot van Lobola. So het Jock Silberstein of dr. Johns bepaalde lewensbeskouings en Godsbeskouings wat hulle in die stuk fiksie duidelik verkondig maar wat ons nie sonder meer as synde dié van die skrywer sou kan bestempel nie.

Feit is egter dat die lewensbeskoulike element 'n aktiewe en belangrike struktuurmoment in die sinvolle verhaal kan wees, meestal ook in ons hedendaagse Afrikaanse prosa is. En hierdie lewensbeskouing uaarvan die romanfigure op die hele roman dic gedramatiseerde epiese konkretisering is, kan lynreg te staan kom teenoor dié van die leser of literator, soos bv. geblyk het i.v.m. die polemiek oor die bekroning van Sewe dae en die geskryf in bv. "Die Burger" n.a.v. Brink se werk wat nou nog aan die gang is. Indien die verhaal tot die anekdotiese beperk bly, sou dit seker effens moedswillig wees om die lewensbeeld of waardes of Godsbeskouing daarin ernstig te gaan aanval. Maar nou is daar juis in die moderne prosakuns soveel interne getuienis dat die verhaal streef na algemene geldigheid of universaliteit, deur die gebruik van 'n mitiese basis bv. of elkerlykfigure. Omdat die verhaal pretendeer om 'n algemeen-geldende waarheid te bevat en hom hiervoor beroep op 'n sekere gesag, juis daarom kan en mag ek dit op grond van ander gesag, die Bybel bv., betwis indien nodig.

V. So kom dan nou in die vyfde plek die werkwyse van die leser-kritikus-literator ter sprake. Die literator wat ek bedoel, is die een wat die vroeër aangeduide lewens- en wêreldbeskouing deel en uitleef, maar hy is ook ontwyfelbaar literatuurkundige. Hy sien bv. die roman in sy eie reg; hy erken die wesenlikheid van die literatuur en sy soorte; hy ondersoek bv. die verhaal op letterkundige-strukturele wyse, en nie as 'n betoog, ' $n$ lewensnit of wat ook al nie. In hierdie verband haal ek eerstens met instemming aan die woorde van prof. G. Dekker.

In sy behartigenswaardige opstel oor die Calvinisme en die kuns in Oordeel en besinning verklaar hy onder meer: „In 
die laaste instansie word ook 'n kunswerk geoordeel as lewenswaarde, word dit gestel teenoor die beoordelaar se hele stelsel van lewenswaardes, sy lewens- en wêreld- en Godsbeskouing". Hy sê ook eksplisiet dat in die Calvinistiese kunskritiek bo- of buite-estetiese norme 'n rol sal speel.

Ek sou wil byvoeg dat dít juis die groot eis aan bv. dié literator is: om die juiste balans tussen estetiese en nieestetiese norme te vind en wetenskaplik verantwoord te handhaar.

Dit lyk my onvermydelik dat die Calvinistiese literatuurkundige en kritikus só openlik standpunt moet inneem t.o.v. sy werkwyse en beoordelingsnorme. Persoonlik bevredig dit my nie om te sê dat die leser nie die lewensbeskouing van die boek deelagtig hoef te wees nie, maar dat hy slegs moet vasstel en ervaar of die kernwaarhede daarin eerlik deurleef en op ' $n$ verantwoordelike manier esteties verwerk is. Dit is bv. 'n standpunt gehuldig deur 'n literator wie se kredensiebriewe as mens en letterkundige bo twyfel staan. Baie hang natuurlik af van wat met „verantwoordelike manier" bedoel word.

Ook die woorde van 'n verantwoordelike teoloog los m.i. nog nie die probleem van werkwyse op nie. Hy beweer dat die literator wat die gesag van Gods Woord erken en met struktuur èn materiaal rekening hou, morele valsheid deur ongeïntegreerdheid in die totaliteit van die struktuur sal ontdek. Morele valsheid miskien, maar immoraliteit in 'n bepaalde soort struktuur? Nee, die praktyk dwing 'n mens wat bepaalde opvattings het om soms nie-estetiese maatstawwe as finale en hoogste toets aan te lê.

VI. Ons aanvaar en ervaar dat daar botsing tussen lewensbeskouing en literatuur kan wees en wel bestaan. Teoretici het hieroor geskryf en ek haal net twee aan wie se reputasie as literatore eweneens bo verdenking staan. Die probleem word erken, en oplossings aan die hand gedoen.

I. S. Eliot beweer: „When the doctrine, theory, belief, or 'view of life' presented in a poem is one which the mind of the reader can accept as coherent, nature, and founded on facts of experience, it interposes no obstacle to the reader's enjoyment, whether it be one that he accept or deny, approve or deprecate".

Ook hierdie oplossing raak nie die diepste wese van die 
probleem nie. Ook nie die soort ontwyking wat Van Wyk Louw openbaar wanneer hy hom soos volg uitlaat nie: die taak van die godsdiens is om te stry teen die sondige in die mens en die taak van die kuns is om die lewe so volledig en waar as wat hy kan uit te druk; in 'n onvolmaakte wêreld sal dié twee pligte moet bots - 'n volkome sameval van die twee is alleen denkbaar in 'n sondelose, volmaakte wêreld.

Laat ek dus by hierdie sesde en voorlaaste punt die probleem soos volg resumeer:

Moet ek enige lewensbeskouing of Godsbeskouing wat in ' $n$ boek ingebed is, sonder kommentaar aanvaar mits dit eerlik deurleef en esteties verwesenlik is? M.a.w. kan ek bv. Gerard Walschap se determinisme of Marnix Gijsen se skepsis aanvaar binne die konteks van 'n geslaagde roman, hoewel ek as Calvinis dié beskouings nie hoef te deel nie, dit maar so sito-sito onbevraagteken laat verbygaan? Of die in Sewe dae of Lobola of Die ambassadeur? Ons kan ter wille van die argument heeltemal veilig aanneem dat dié Afrikaanse boeke, soos ook bv. dic Nederlandse De familie Roothooft of Klaaglied om Agnes literêr gaaf genoeg is, want anders sou ons hulle bloot as 'n wanvorm van die kuns kon verwerp en as onwaardig vir beskouing.

Maar nou: juis daardie lewensbeskouing wat die skrywer in 'n bepaalde boek gangbaar maak, laat hom sekere beeldingsmiddele gebruik wat ek as literator (wat ook mèns is) volgens die godsdienstig-sedelike norme van die Bybel verwerplik en sondig vind. Bv. die onsedelikheid in die kaserne (Klaaglied om Agnes) of die ontug in Die ambassadeur: die hele verhaal hier is, grofweg gestel, gebaseer op egbreuk; of Henry van Eeden se besoek aan die ontughuisies - ek verwys spesifiek na die palmolive seepparagraaf. Jock Silberstein se Godsbeskouing in Sewe dae sou bv. ook heeltemal strydig wees met die Godsopenbaring soos die Calvinis dit uit die Bybel ken. Weliswaar word die geldigheid van Jock se Godsbeskouing in twyfel getrek deur dr. Johns en regter o'Hara, maar binne die romanstruktuur beklee Jock 'n bevoorregte en dus meer invloedryke posisie.

Binne die raamwerk of struktuur van die bóék is dié sake esteties miskien volkome op hulle plek en funksioneel. Die lewensbeskouing, tema of idee van die verhaal is esteties verwesenlik in die roman, op die verhaalmatige wyse van die roman, nl. dramaties-beeldend en sinvol. 
As jy dus bloot struktureel te werk gaan in jou ontleding, gaan jy min of geen fout vind met die hoofsake in Sewe dae of Die ambassadeur nie. Die Godsbeskouing, egbreuk of ontug waarteen jy beswaar het, gaan jy nie op dié wyse veroordeel nie. En beswaard voel jy, al besef jy ook dat ' $n$ mens die lig die helderste sien in teenstelling tot die duisternis, dat daar 'n moontlike etiese of ander waarde in 'n moontlike keerbeeld opgesluit mag lê. Maar dit is duidelik dat alles wat volgens Skriftuurlike norme verwerplik is, nie noodwendig weens onvolkome strukturcring of ongeïntegreerdheid aanwysbaar sal wees nie.

Soms dek strukturele swakhede wel sulke besware, en ek sou voorbeelde kon aanwys:

In Die ambassadeur maak een van die karakters die Calvinisme (met ' $n$ klein $c$ ) af met ' $n$ sin of twee as reglynig, higiënies, te star, verbeeldingloos, nugter. Maar hierdie uitspraak wat ek met die eerste lees begryp het as venynig, is ook binne die struktuur van die roman ongeldig, omdat die karakter se uitspraak nie op 'n aanvaarbare ervaring en kennis berus nie. Die verhaal demonstreer nooit hoe hy kennis opgedoen het van "die" Calvinisme waaroor hy dit nou het nie. Maar net daarna demonstreer die verhaal uitvoerig die teatrale en die mistiek van die Rooms-Katolieke middernagtelike Kers-Mis. Iemand anders, èk bv., sou dít weer kon afmaak as paapse superstisies. Let wel, alles kom op rekening van die verhaalkarakters, maar dit laat die roman inboet aan daardie balans en voldraenheid wat 'n boek werklik gróót maak. Nietemin is dit nog nie die hoofsaak in die roman nie.

Op ewe suiwer struktureel-estetiese uyse sou ek my morele besware teen 'n boekie soos Julius Caesar deur dieselfde outeur kon staaf. Dié werkie is een van 'n reeks bedoel vir die jeug van Suid-Afrika. Maar wat 'n onverkwiklike en weinig verheffende geskiedenis vertel hierdie boek nie: die verhaal van Julius Caesar is een van grenselose ambisie, selfsug, konkelary, onderduimsheid, wreedheid, geweld, egbreuk, selfvergoding. Die waardes wat hierdie vertelling in hoofsaak huldig, staan lynreg teenoor dié wat ' $n$ mens jou kind wil leer. Daar is dus 'n didaktiese besuaar: die boek verydel m.i. die opvoedkundige doel van die reeks. Maar meer, daar is 'n suiwer letterkundig-strukturele teenstrydigheid: Julius Caesar word hier op dié wyse as 'n held, een van die grotes van die mensdom voorgehou. Aan die einde lees ons: „Caius Julius 
Caesar is dood. Maar tog leef hy voort omdat hy in grootheid en menslikheid bo alle tydelike grense verhewe is". Die verhaal egter wat dié woorde voorafgaan, maak hulle 'n aanfluiting.

So maklik is die taak egter nie altyd nie - ek vestig bv. die aandag op die ongebreidelde sinlikheid/seksualiteit en religieuse perversiteit van die heksesabbat in Sewe dae. Struktureel is alles in orde; 'n mens sou selfs kon bewys dat daar voldoende estetisering van die grondstof plaasgevind het.

Die crux van die probleem is dus: Moet ek onkrities as kuns aanvaar wat ek lewensbeskoulik verwerp, dit aanvaar net omdat dit kuns geword het? Is die hoogste gesag in die literatuurbeskouing van die Calvinis die estetiese wanneer die estetiese bots met die godsdienstige en/of die sedelike wat op sy beurt steun op die religieuse? $\mathrm{Ek}$ as leser/literator is nie net esteet nie; ek is mens. Anders gestel: moet ons die immorele aanvaar as dit geëstetiseer is, bv. 'n verhaal met as boustof die besoek aan 'n ligtekooi - vgl. Windroos.

Dus, as die Boek (met 'n hoofletter) sê egbreuk is sonde en verwerplik, kan ek 'n boek (klein letter) aanvaar waarin egbreuk en ontug as 'n beeldingsmiddel of struktuurmiddel aangewend word soos in Lobola of Die ambassadeur?

Uiteindelik is die vraag selfs of àlles in die lewe wel geëstetiseer kan word, maar dis al weer 'n nuwe probleem. Op die oomblik gaan dit my net om boustof wat bewysbaar geëstetiseer is maar wat morele en/of godsdienstige vraagstukke aan die orde stel.

VII. Ten slotte kan 'n mens nou vra: is daar ' $n$ antwoord, is daar ' $n$ oplossing vir hierdie besondere botsing tussen estetiek en godsdiens of etiek? Dit lyk my in die eerste plek gebiedend om met 'n oop gemoed die saak te benader maar ook wel heslis op te tree. As vakman en as Calvinis wat 'n oop oog vir die werklikheid het, sou jy kennis moet neem van alles wat daar van noemenswaardige gehalte in jou taal (ook ander tale as jy kan) verskyn, en die kwaliteit van die publikasies probeer bepaal volgens hul samehang en omvang: m.a.w. die geslaagdheid as woordkunswerk, -bouwerk en die digtheid, rykdom of seggingskrag van die inhoud vasstel.

Maar jy sal moet in gedagte hou dat ons in die wêreld na die sondeval lewe, dat daar 'n element van waarheid mag 
wees in Opperman se radikale stelling in sy opstel Kuns is boos!: die kuns werk dikwels met bose middele, maar sy doel is iets goddeliks; ook onthou dat daar so iets is as die algemene genade van God, dat selfs Bileam kan seën in plaas van vervloek. Ek wil dit baie duidelik stel dat ek as Calvinis die eiesoortigheid van die kuns nie wil ontken nie - die kuns (dus ook die letterkunde) staan nie in diens van die godsdiens of teologie of politiek nie. Maar die kuns moet wees tot eer van die Drie-enige God van die Heilige Skrif, al is dit slegs in dié sin dat dit nie tot oneer van God en tot skade van die mens as beelddraer van God is nie. Hiermee hang saam dat sekere leuensfasette in die kuns nie verabsoluteer moet word (die ware aard van die geskapene nie misken moet word) soos bv. die seksuele in Orgie nie, of dat die kuns self nie verabsoluteer moet word nie. 'n Mens dink onwillekeurig aan die antwoord van Jesus (Lukas $21: 5$ ) toe sy aandag op die mooi klippe en versiering van die tempel gevestig is.

Dus moet ek nie huiwer nie om op die voortreflikheid van 'n stuk woordkuns te wys, mits dit so is, al sou die lewensbeskouing, boustof of beeldingsmiddele ook vir my vreemd of verwerplik wees. Maar dan moet ek ook sê wát verwerplik is, getuig van my norme en die gesagsbron daarvan. Ek vir my, kan nie 'n neutrale wetenskaplike wees nie, of 'n verkleurmannetjie van boek tot boek. En laat ek dit duidelik stel: so 'n standpunt is nie blote subjektivisme nie: ek hou van/ek hou nie van nie. Nee, jy gaan so suiwer moontlik literêr-esteties te werk, maar jy stel ook die literêr-estetiese norme ondergeskik aan die Woord van God. Maar, ek sê dit weer, met die grootste omsigtigheid en verantwoordelikheid omdat die Heilige Skrif geen estetiese handboek is nie.

As 'n mens dié standpunt inneem, mag jy 'n eensame wees, maar jy vind ook ondersteuning by enkele verantwoordelike denkers oor dié saak, soos twee hoog aangeskrewe en ontwyfelbaar gedeë literatuurkundiges wie se name ek in hierdie verband agtergehou het tot nou, nl. Cleanth Brooks en Robert Penn Warren. In hulle standaardwerk oor die verhalende prosa, Understanding fiction, verklaar hulle op bl. 276: „We must simply recognize that some writers, and some stories, offend us at too deep a level. They embody some attitude toward life, some set of values which denies our oun very basis of life ... In a situation like that we are bound to 
acknowledge the fact and deal with it. We reject the story, just as we would reject a person in real life".

Hulle is by my wete die enigstes wat hulle op skrif so positief uitlaat. Ek onderskryf graag hierdie woorde en behou daarmee vir my die reg voor om indien nodig 'n literêre kunswerk te mag verwerp of te kritiseer op grond van bo- of buiteestetiese Skrifgefundeerde norme, al word sulke maatstawwe dan vandag nog meestal beskou as ingesmokkelde kontrabande. P.U. vir C.H.O., P. D. van der Walt. Potchefstroom.

\section{GEOLOGIESE TYD OF OSEAANDIEPTE?}

Die fossielelae van die paleontologie skep vir die natuurwetenskaplike sowel as die teoloog oënskynlik onoorbrugbare vraagstukke. Vir die natuuruetenskaplike spreek dit van kronologiese opeenvolging van lewe op aarde ooreenkomstig 'n patroon wat oor die algemeen dui op 'n miljoene jare-proses van die primitiefste tot die mees ingewikkelde bouvorms. Hierdie verskynsel suggereer al dadelik die waarskynlikheid van ' $n$ deurlopende evolusieproses wat oor miljarde jare voltrek is. Die belangrikste vraagstuk waarvoor aanhangers van so 'n teorie te staan kom, is die algehele afwesigheid van oorgangsvorme wat tussen dic verskillende fossielelae moes gevind gewees het indien daar sprake was van genetiese verband. Op die verskillende uitvlugte hoef hier nie ingegaan te word nie, behalwe om prof. J. Lever aan te haal wat verklaar dat indien so 'n proses wel plaasgevind het, dit geskied het op 'n uyse wat vir die wetenskaplike tans nog onbekend is.')

Dat evolusic tussen soorte plaasgevind het, bly dus onbewese. Wat oënskynlik egter wel vasstaan, is dat die ouderdom van lewe op aarde in miljoene jare bereken moet word indien uitgegaan word van geologiese tydberekening. Dat hierdie berekening gegrond is op die evolusie-opvatting, moet rekening mee gehou word. Dit berus enersyds op Lyell se aktualiteitsbeginsel wat 'n voortdurende en geleidelike proses op geologiese gebied veronderstel waarbinne die evolusieproses voltrek sou word, en andersyds op ouderdomsbepaling van aardlae deur middel van hul fossiele-inhoud, wat inhou dat 'n skatting gemaak word ooreenkomstig 'n veronderstelde evolusieproses, waarvan die aard - en gevolglik ook die duur - tot hede toe nog steeds 'n saak van loutere spekulasie bly.

Krumbein verklaar in 1963 in verband hiermee as volg: 